\title{
OPTIMASI HASIL MELON (Cucumis melo, L) PADA TANAH PODSOLIK MERAH KUNING DENGAN MENGGUNAKAN PUPUK BIO ORGANIK
}

\author{
SURTINAH SURTINAH ${ }^{*}$, dan SEPRITA LIDAR ${ }^{2}$ \\ ${ }^{1,2}$ Prodi Agroteknologi Fakultas Pertanian Universitas Lancang Kuning \\ Jl. Yos Sudarso, Km.8 Rumbai, Pekanbaru \\ e-mail : surtinah@unilak.ac.id
}

\begin{abstract}
ABSTRAK
Tanah Podsolik Merah Kuning (PMK) merupakan jenis tanah yang mendominasi kondisi tanah di Pekanbaru, Tanah PMK dengan kesuburan yang rendah akan menjadi factor pembatas dalam meningkatkan produksi tanaman. Melon merupakan tanaman hortikultura yang menghendaki tanah yang subur dan gembur. Herbafarm adalah salah satu pupuk bioorganic yang mampu menutupi kekurangan tanah PMK untuk meningkatkan produktivitasnya. Rancangan perlakuan yang diuji adalah konsentrasi Herbafarm yang terdiri dari $\mathrm{H}_{1}=$ tanpa herbafarm; $\mathrm{H}_{1}=$ herbafarm $2 \mathrm{ml}$ liter $^{-1}$ air; $\mathrm{H}_{2}=4 \mathrm{ml}$ liter ${ }^{-1}$ air; $\mathrm{H}_{3}=6 \mathrm{ml} \mathrm{liter}^{-1}$ air; dan $\mathrm{H}_{4}=8 \mathrm{ml} \mathrm{liter}^{-1}$ air. Rancangan lingkungan yang digunakan adalah rancangan acak lengkap. Analisis data menggunakan regresi polynomial. Konsentrasi Bio Organik Herbafarm yang memberikan pertumbuhan dan hasil melon adalah $6.8 \mathrm{ml} \mathrm{liter}^{-1}$ air, dengan berat buah optimal 1683.08 gram.
\end{abstract}

Kata kunci : Herbafarm, Melon, PMK, Regresi polynomial.

\section{ABSTRACT}

Red Yellow Podsolic Soil (FMD) is a type of soil that dominates soil conditions in Pekanbaru, PMK soil with low fertility will be a limiting factor in increasing crop production. Melon is a horticultural plant that requires fertile and loose soil. Herbafarm is one of the bioorganic fertilizers that can cover the shortage of PMK land to increase its productivity. The treatment design tested was Herbafarm concentration consisting of $\mathrm{HI}=$ without herbaceous; $\mathrm{HI}=$ herb $2 \mathrm{ml}$ liter- 1 water; $\mathrm{H} 2=4 \mathrm{ml}$ liter- 1 water; $\mathrm{H3}=6 \mathrm{ml}$ liter- 1 water; and $\mathrm{H} 4=8 \mathrm{ml}$ liter- 1 water. The environmental design used is a completely randomized design. Data analysis uses a polynomial regression. Bio Organic Concentration Herbafarm which gives growth and melon yield is $6.8 \mathrm{ml}$ liter-1 water, with an optimal fruit weight of 1683.08 grams.

Keywords: Herbafarm, Melon, PMK, Polynomial regression

Diterima: 27 Februari 2019, disetujui 12 April 2019

\section{PENDAHULUAN}

Tanah PMK yang mendominasi sentra produksi pertanian di Pekanbaru, menjadi salah satu penghambat untuk meningkatkan produksi pertanian, terutama tanaman hortikultura. Tanaman hortikultura umumnya menghendaki tanah yang subur, gembur, dan cukup mengandung bahan organik (Surtinah, 2018 a). Komponen yang menjadi penghambat pada tanah PMK dapat diatasi 
dengan pemberian bahan organic yang cukup dan pupuk organic maupun anorganik yang memadai (Surtinah, 2018 b).

Tanah PMK yang dikelola dengan baik akan berdayaguna, karena dapat menyediakan unsur hara baik makro dan mikro yang dibutuhkan oleh tanaman. Unsur-unsur hara yang diberikan ke tanah PMK bersumber dari bahan organic maupun anorganik. Pupuk bioorganik yang dapat meningkatkan kemampuan tanah PMK adalah Herbafarm. Pupuk ini mengandung nutrisi organik yang bermanfaat bagi tanaman diantaranya Corganik $6,39 \%, \mathrm{~N} 2,24 \%, \mathrm{P} 2 \mathrm{O} 51,91 \%$, K2O 1,81\%, Seng (Zn) 0,002\%, Tembaga (Cu) 2,49 ppm, Mangan (Mn) 0,003\%, Kobalt (CO) 0,74 ppm, Boron (B) 0,100 $\%$, Molibdenum (Mo) $<0,001 \%$, Besi (Fe) $0,028 \%$. Disamping itu juga mengandung mikro organisme tanah yang bermanfaat sebagai dekomposer (pengurai) dan penyedia nutrisis dari alam seperti mikroorganisme Azotobacter sp; Azosprillium sp; bakteri pelarut $\mathrm{P}$; Lactobacillus sp; Psedomonas sp; bakteri selulotik; mengandung asam humat, asam fulfat dan hormon tanaman. Herbafarm mengandung unsur - unsur hara makro dan mikro dan juga senyawa organik yang sangat penting bagi pertumbuhan dan perkembangan tanaman (Anonim, 2012).

Surtinah (2017) menjelaskan bahwa unsur makro yang terkandung di dalam pupuk akan memperpanjang umur tanaman, yang mengakibatkan proses fisiologi pada tanaman akan berlangsung lebih lama, yang akan ditimbun sebagai bahan kering pada proses produksi tanaman. Aritonang dan Surtinah ( 2018) melaporkan bahwa tanah PMK yang diberi bahan organik mampu memberikan hasil yang lebih baik, bila disertai dengan pemberian pupuk organik.pada lokasi penanaman. Setiadi dan Parimin (2006) menyatakan hal yang sama yaitu tanaman melon akan tumbuh optimal apabila kondisi lahan mengandung bahan organic yang berlimpah. Tanah dengan porositas yang tinggi dan tanah dengan porositas yang rendah dapat diperbaiki menjadi lebih baik dan berdayaguna (Matenggomena, 2013).

Herbafarm mengandung unsur hara makro dan mikro yang dapat mempengaruhi pertumbuhan panjang dan lingkar batang tanaman melon (Ode, dan Bahrun, 2012). Herbafarm mengandung senyawa esensiel yang dibutuhkan tanaman, dan mikroba bio fertilizer yang dibutuhkan oleh tanaman dalam membantu proses penyerapan hara oleh tanaman, akibatnya kondisi biologi, kimia dan fisik tanah menjadi lebih kondusif untuk pertumbuhan dan perkembangan tanaman (Syofia, Alridiwirsah, dan Saleh, 2015).

C-organik yang terkandung di dalam tanah menjadi nutrisi penting untuk tanaman, karena dapat memperbaiki struktur tanah, dan menjadi makanan bagi mikroorganisme tanah, kondisi ini menguntungkan untuk perkembangan akar tanaman dan aerasi tanah (Elisabeth, 2013). Mikroorganisme seperti Azotobacter sp, Azospirillium, bakteri pelarut fosfat, Lactobacillus, Pseudomonas sp, yang terkandung di dalam Herbafarm sangat membantu dalam proses ketersediaan hara di dalam tanah (Surtinah, 2018).

Isminarni, Wedhastri, dan Purwanto (2007) melaporkan bahwa Azotobacter dan Azospirillium akan menambat $\mathrm{N}$ berbanding lurus dengan jumlahnya. Bacillus sp dan Pseudomonas $s p$ akan menyediakan $\mathrm{P}$ tersedia bagi tanaman. Whitelaw (2000, dan Anianty, 2008)) membuktikan bahwa Pseudomonas sp menjadi agen pengendalian penyakit tumbuhan, dan dapat meningkatkan kekebalan tanaman terhadap infeksi jamur pathogen akar, bakteri dan virus.

Syofia et al. (2015) melaporkan bahwa tanaman semangka yang diberi 
Herbafar $4 \mathrm{ml}^{-1}$ air berpengaruh sangat nyata terhadap umur berbunga, jumlah buat per tanaman dan berat buah semangka, sedangkan Asrul, Rofer, dan Mashadi (2012) melaporkan bahwa pemberian bio organic Herbafar $3 \mathrm{ml}$ liter

\section{METODE PENELITIAN}

Penelitian dilaksanakan pada bulan Nopember 2017 - Januari 2018, di kebun Percobaan Fakultas Pertanian Unilak, dengan ketinggian tempat 20 meter dpl. Jenis tanah PMK.

Bahan yang digunakan adalah benih Melon varietas Sakata Glamour, Media tanah PMK, pupuk kandang sapi, Pupuk Herbafarm, dan NPK Mutiara 16:16:16, polybag ukuran $8 \times 12 \mathrm{~cm}$ Dithane M-45, Curacron 500 EC, dan Petrogenol, tali rafia. Alat yang digunakan adalah cangkul, meteran, pisau, ember, kayu, bambu, kalkulator, parang, cutter, gergaji, martil, jangka sorong, meteran, hands sprayer, polybag, timbangan, refractometer, karton, kamera, dan alat tulis.

Rancangan lingkungan yang digunakan adalah rancangan acak lengkap dengan 4 kali ulangan. Rancangan perlakuan yang diuji adalah: konsentrasi Herbafarm yang terdiri dari 5 taraf, yaitu: $\mathrm{H}_{0}=$ tapa herbafarm; $\mathrm{H}_{1}=$ pemberian Herbafarm 2 ml liter $^{-1}$ air; $\mathrm{H}_{3}=$ Herbafarm 4 liter $^{-1}$ air; $\mathrm{H}_{4}=6 \mathrm{ml} \mathrm{liter}{ }^{-1}$ air; dan $\mathrm{H}_{5}=$ Herbafarm $8 \mathrm{ml} \mathrm{liter}^{-1}$ air. Analisis data menggunakan regresi polynomial.

Lokasi penelitian diolah sebanyak dua kali pengolahan Pencangkulan pertama bertujuan membongkar perakaran dan membalik tanah, sedangkan pencangkulan kedua bertujuan menggemburkan dan menghaluskan tanah. Pada pencangkulan kedua ditambah dengan pemberian pupuk kandang sebagai pupuk dasar sebanyak $5 \mathrm{~kg}$ per plot, lalu tanah diratakan dan dibuat bedengan bedengan plot dengan ukuran $1,6 \mathrm{~m} \mathrm{x} 1 \mathrm{~m}$ dengan tinggi $25 \mathrm{~cm}$, sebanyak 20 plot
1 air berpengaruh nyata terhadap umur panen jagung manis. Tujuan penelitian adalah untuk mendapatkan konsentrasi Bio Organik Herbafarn yang memberikan hasil terbaik tanaman melon.

dengan jarak tanam $80 \mathrm{~cm}$ x $50 \mathrm{~cm}$ dengan jarak antar plot $50 \mathrm{~cm}$

Benih Melon direndam dalam air hangat selama 10 jam kemudian dikecambahkan selama 2 hari diatas kain kasa dan dijaga kelembabannya. Setelah berkecambah, benih lalu disemaikan dalam polybag $8 \times 12 \mathrm{~cm}$ yang telah diisi campuran tanah (top soil) PMK dan pupuk kandang dengan perbandingan $2: 1$ (dua tanah top soil dan 1 pupuk kandang) setiap polybag diisi 1 benih melon dengan kedalaman $1,5 \mathrm{~cm}$.

Penanaman dilakukan 1 minggu setelah pengolahan tanah kedua, penanaman dilakukan dengan memindahkan bibit yang berumur 14 hari dari tempat persemaian ke plot yang sudah siap dengan jarak tanam $80 \times 50$.

Pemberian pupuk herbafarm diberikan satu minggu setelah tanam sebanyak 7 kali. Pencampuran perlakuan dilakukan dengan cara pupuk Herbafarm sesuai taraf perlakuan dicampurkan dengan air bersih hingga mencapai 1000 ml. Pemberian dilakukan dengan cara disemprotkan ke tanah dan ke tanaman. Sedangkan tanaman yang tidak diberikan perlakuan tetap diberikan perlakuan disemprot dengan menggunakan air.

Penyiraman dilakukan 2 kali sehari pagi dan sore hari dengan volume yang sama yaitu $1 \mathrm{~L}_{\text {tanaman }}^{-1}$.

Pemasangan lanjaran atau ajir dilakukan sejak tanaman berumur 2 hari setelah tanam. Ajir terbuat dari kayu dengan panjang 2 meter.

Pupuk yang diberikan sebagai pupuk tambahan adalah NPK mutiara (16:16:16) diberikan empat kali selama 
budidaya dengan dosis setengah anjuran 40 gram tanaman ${ }^{-1}$. Pemberian pupuk diberikan $10 \mathrm{~g} \mathrm{tanaman}^{-1}$ yang diberikan dengan cara ditugal.

Pemangkasan dilakukan pada tanaman melon yaitu dengan pembuangan tunas-tunas baru dan bunga yang tumbuh pada ketiak daun. Tunas yang dipangkas adalah tunas yang muncul pada ruas ke-1 sampai ke-8, sedangkan tunas yang tumbuh di ketiak daun pada ruas ke-9 sampai ke-13 dipelihara untuk memperoleh buah sementara sebelum dilakukan seleksi. Tanaman yang sudah mencapai ruas ke-25 dilakukan pemangkasan titik tumbuh bertujuan untuk mengoptimalkan perkembangan buah.

Seleksi buah dilakukan setelah buah berukuran sebasar telur ayam $(4 \mathrm{~cm})$ dengan memilih buah yang berbentuk agak lonjong. Dalam satu tanaman disisakan 2 buah per tanaman dengan kriteria sehat dari serangan hama dan penyakit. Pengikatan dilakukan dengan cara tangkai buah diikat dengan tali rafia pada turus bambu agar buah tidak bersentuhan langsung dengan tanah. Dilakukan pada tanaman berumur 15 hari setelah terbentuk buah.

\section{HASIL DAN PEMBAHASAN}

\section{Pertumbuhan Vegetatif Tanaman}

Pengamatan terhadap pertumbuhan vegetatif tanaman melon dilakukan pada dua organ yaitu lebar daun dan diameter batang. Hasil regresi menunjukan bahwa pupuk Bio Organik Herbafarm sangat berperan dalam
Pengendalian hama dan penyakit dilakukan penyemprotan dengan insektisida Curacron 500 EC $2 \mathrm{cc} \mathrm{liter}^{-1}$ air Dithane M-45 2 gr liter ${ }^{-1}$ air seminggu setelah tanam. Penyemprotan dilakukan dengan interval waktu dua minggu sekali secara selang seling dan diakhiri seminggu sebelum panen. Untuk melindungi buah dari serangan lalat buah, dilakukan pembungkusan buah muda dengan kantong plastik bening, serta memasang perangkap dengan menggunakan petrogenol yang dimasukkan dalam botol aqua bekas.

Tanaman melon dipanen dengan kriteria adanya rekahan menyerupai cincin antara pangkal tangkai buah dengan buahnya, warna kulit buah berwarna hijau kekuningan, dahan dan daun kelihatan menua. Pemetikan dilakukan pada saat cuaca cerah dengan hati-hati menggunakan gunting.

Pengamatan untuk mencapai tujuan penelitian dilakukan terhadap: Umur panen (hari), Lebar Daun (cm), Diameter batang $(\mathrm{cm})$, Lingkar Buah (cm), Berat Buah (g), Tebal Daging Buah (cm), dan Kadar Gula (\%).

menstimulir pertumbuhan daun dan batang tanaman melon. Kondisi tersebut dibuktikan dengan koefisien korelasi dari kedua parameter yang diamati tinggi yaitu 0.94 untuk lebar daun dan 0.84 untuk diameter batang. 

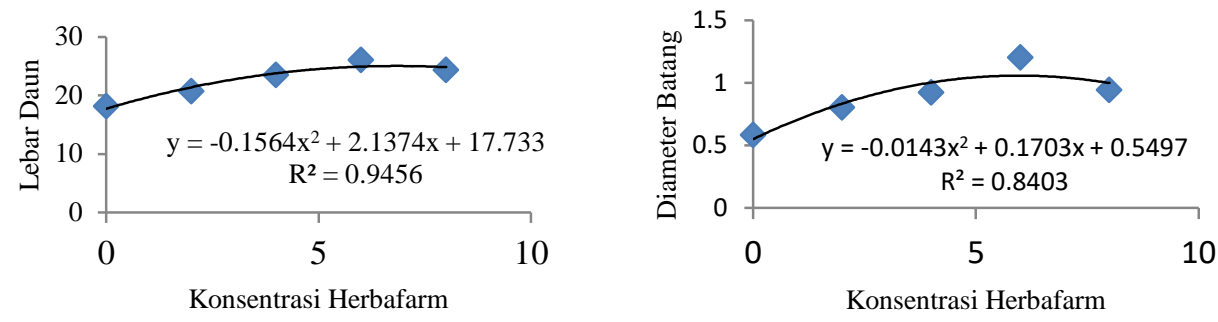

Gambar 1. Hubungan antara konsentrasi Bio Organik Herbafarm dengan Lebar Daun dan Diameter batang Melon

\section{Pertumbuhan Generatif}

Pengukuran yang dilakukan terhadap pertumbuhan generatif memperlihatkan hubungan yang sangat erat antara konsentrasi pupuk Bio
Organik Herbafarm yang diberikan ke tanaman melon. Keeratarn hubungan tersebut direkap dalam Tabel 1. Berikut ini;

Tabel 1. Rekap keeratan hubungan antara konsentrasi Bio Organik Herbafarm terhadap Pertumbuhan Generativ Tanaman Melon.

\begin{tabular}{lcc}
\hline \multicolumn{1}{c}{ Parameter pengamatan } & Koefisien Korelasi & Keratan Hubungan \\
\hline Umur Panen & 0.85 & Sangat kuat \\
Lingkar Buah & 0.98 & Sangat kuat \\
Berat Buah & 0.89 & Sangat kuat \\
Tebal Daging Buah & 0.98 & Sangat kuat \\
Kadar Gula & 0.89 & Sangat kuat \\
\hline
\end{tabular}

Sumber :(Sugiyono, 2007)

Keeratan hubungan antara persamaan garis regresi seperti gambar pemupukan dengan produksi tanaman berikut ini.

melon digambarkan berdasarkan
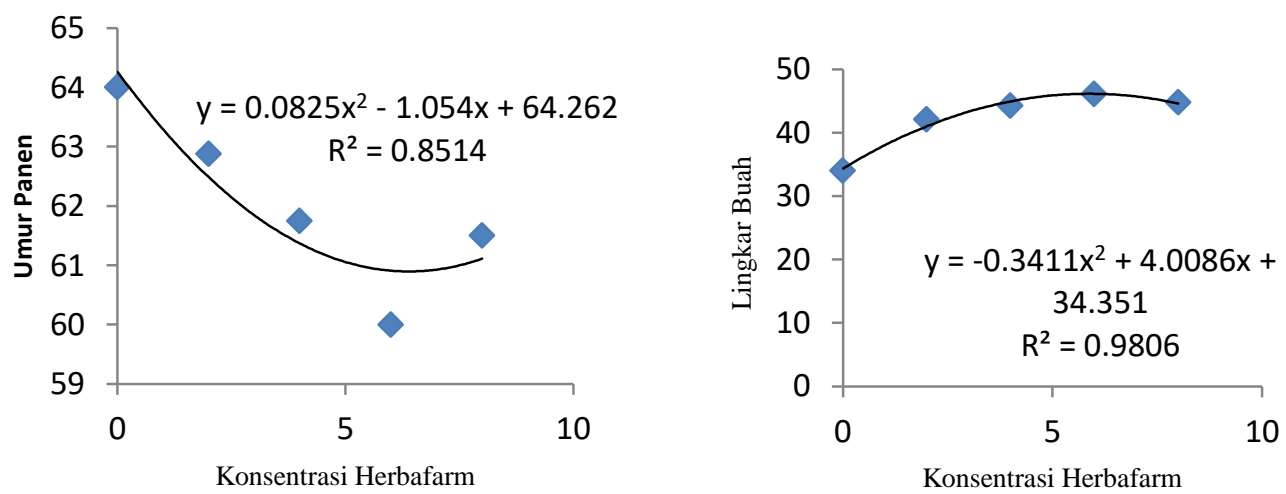

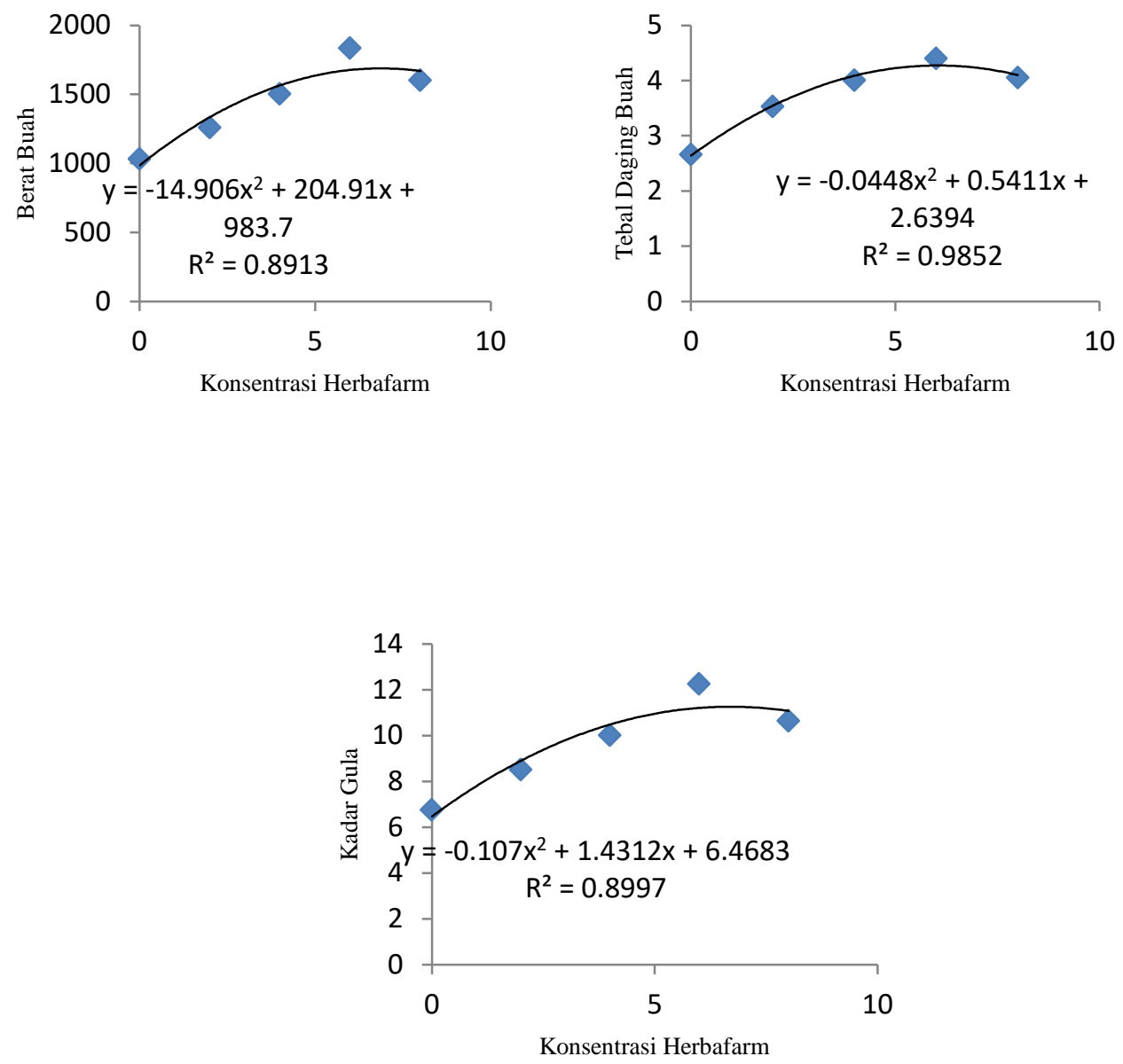

Gambar 2. HUbungan antara konsentrasi Bio Organik Herbafarm dengan Pertumbuhan Generativ Tanaman Melon.

\section{Pembahasan}

Pengamatan terhadap pertumbuhan vegetatif dan generatif menghasilkan luas daun dan diameter batang sangat erat hubungannya dengan pemberian konsntrasi Bio Organik Herbafarm. Kondisi ini membuktikan bahwa Herbafarm mampu meningkatkan pertumbuhan dan produksi tanaman melon. Tabel 2. Berikut ini akan memperlihatkan hasil optimum konsentrasi Herbafarm yang memberikan pertumbuhan dan hasil yang optimum pada tanaman melon.

Data pada Tabel 2. Menjelaskan tentang konsentrasi optimum pupuk Bio
Organik Herbafarm yang bisa digunakan sesuai dengan tujuan budidaya melon yang ingin dicapai. Konsentrasi optimum yang dianggap paling baik untuk menstimulir pertumbuhan dan produksi melon adalah $6.8 \mathrm{ml}$ liter $^{-1}$ air. Konsentrasi $6.8 \mathrm{ml} \operatorname{liter}^{-1}$ air diambil sebagai konsentrasi representative, hal ini didasarkan pada organ daun merupakan salah satu organ tanaman yang sangat penting dalam menghimpun bahan kering untuk diakumulasikan di dalam organ hasil sebagai komponen produksi dari suatu tanaman.

Tabel. 2. Rekap Optimasi Konsentrasi Bio Organik Herbafarm yang Memberikan Pertumbuhan dan Hasil Optimum pada Tanaman Melon. 


\begin{tabular}{lcc}
\hline \multicolumn{1}{c}{ Parameter Pengamatan } & $\begin{array}{c}\text { Konsentrasi Optimum Bio Organik } \\
\text { Herbafarm }\left(\mathrm{ml} \mathrm{liter}^{-1} \text { air }\right)\end{array}$ & $\begin{array}{c}\text { Pertumbuhan dan Hasil Optimum } \\
\text { Tanaman Melon }\end{array}$ \\
\hline Lebar Daun & 6.8 & $25.04 \mathrm{~cm}$ \\
Diameter Batang & 5.6 & $1.15 \mathrm{~cm}$ \\
Umur Panen & 5.7 & $71.99 \mathrm{hari}$ \\
Lingkar Buah & 5.9 & $46.13 \mathrm{~cm}$ \\
Berat Buah & 6.8 & $1683.08 \mathrm{gram}$ \\
Tebal Daging Buah & 6.0 & $4.27 \mathrm{~cm}$ \\
Kadar Gula & 6.7 & $11.25 \% \mathrm{brix}$ \\
\hline
\end{tabular}

Surtinah (2018) melaporkan bahwa daun tanaman berperan besar dalam pengisian bahan kering ke biji jagung manis dan peranan itu juga terlihat pada akumulasi karbohidrat dalam bentuk gula reduksi pada biji jagung. Pada gambar di bawah ini memperlihatkan keeratan hubungan antara lebar daun dengan berat buah melon. Berat buah melon sangat dipengaruhi oleh lebar daun tanaman melon tersebut, semakin lebar daun maka akan semakin banyak klorofil yang tersedia, dan dengan banyaknya klorofil maka proses fotosintesis yang berperan dalam menghasilkan makanan bagi tanaman akan menyediakan makanan yang cukup untuk digunakan pada proses pertumbuhan dan perkembangan tanaman tersebut.

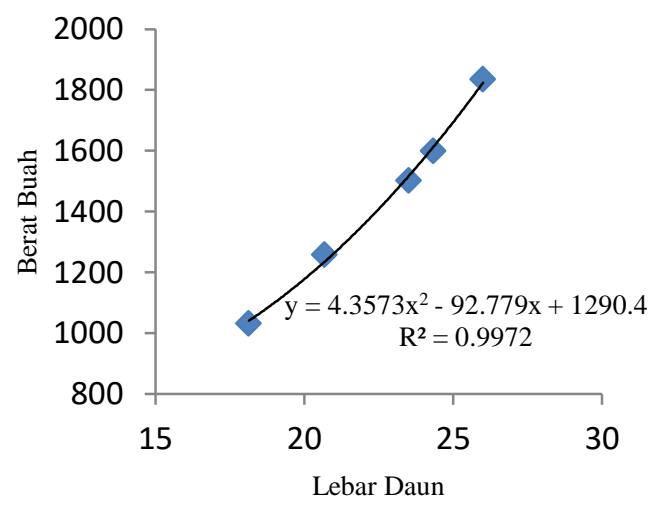

Gambar 3. Hubungan Luas Daun dengan Berat Buah

Herbafarm dengan konsentrasi 6.8 $\mathrm{ml}$ liter $^{-1}$ air diduga dapat berperan aktif dalam menyediakan unsur hara yang dibutuhkan oleh tanaman melon melalui peranan mikroorganisme yang terkandung di dalam pupuk tersebut. Konsentrasi optimal yang diterima oleh tanaman mengakibatkan Azospirillium sp, Azotobacter sp mampu secara maksimal menambat $\mathrm{N}$ sehingga dapat meningkatkan kesuburan tanah (Supriyadi, 2009).
Bacillus sp dan Pseudomonas sp yang terkandung di dalam Herbafarm juga berperan aktif dalam kondisi yang kondusif untuk melarutkan Fosfat menjadi tersedia bagi tanaman untuk digunakan pada pertumbuhan dan perkembangannya (Whitelaw, 2000). Mikroba selulotik yang terkandung dalam Herbafarm diduga mampu mengurai selulosa menjadi glukosa, sehingga dapat dimanfaatkan oleh tanaman sebagai sumber energi, yang mengakibatkan proses metabolism 
semakin baik, sesuai dengan yang sebagai sumber carbon dan energy untuk dilaporkan oleh Lestari (2013), bahwa memacu pertumbuhan dan hasil tanaman. mikroba selulotik menjadikan glukosa

(a)

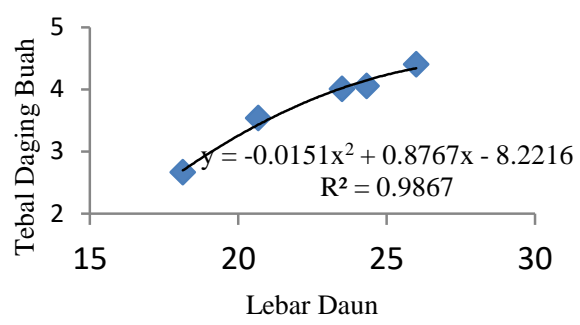

(b)

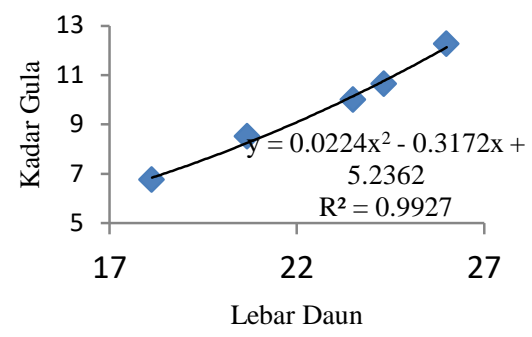

Gambar 4. (a). Hubungan antara Lebar Daun dengan Tebal Daging buah; (b) Hubungan antara Lebar Daun dengan Kadar Gula

C-organik yang tersedia berperan untuk meningkatkan aktivitas biologis tanah dan transportasi unsur hara dan air. Yang akan berdampak pada fotosintesis tanaman dalam menghasilkan cadangan makanannya (Wahida dan Suryaningsih, 2016).

Surtinah (2008) melaporkan umur panen yang tepat pada jagung manis dapat mengahsilkan kadar gula yang tertinggi. Tanaman melon yang dipanen pada umur yang sesuai memberikan kadar gula yang tinggi juga, bila dibandingkan dengan deskripsi dari tanaman melon ini maka kadar gula belum tercapai yaitu $12-13 \%$ brix, sedangkan kadar gula daging buah pada penelitian ini adalah $11.25 \%$ brix. Surtinah (2007) melaporkan bahwa beberapa macam pupuk daun yang diaplikasikan ke jagung manis berpengaruh tidak nyata dalam meningkatkan kadar gula biji jagung manis, fenomena ini membuktikan bahwa pupuk yang diberikan belum mampu untuk menstimulir peningkatan kadar gula biji. Dan pada tanaman melon ini, begitu juga pada tanaman melon.

Konsentrasi yang semakin tinggi yang diberikan pada tanaman melon belum mampu meningkatkan pertumbuhan dan hasil melon. Konsentrasi yang tinggi mengakibatkan jumlah komponen yang terkandung di dalam larutan juga akan tinggi, termasuk di dalamnya adalah jumlah mikroorganismenya. Mikroorganisme yang jumlahnya besar dalam suatu waktu, akan mengakibatkan terjadinya kompetisi dalam memanfaatkan bahan organic dan oksigen. Simanungkalit, Didi,, Rasti, Diah, dan Wiwik (2006) melaporkan bahwa bila mikroba terdapat dalam jumlah yang besar dalam ruang yang sama akan mengganggu kebutuhan nutrisi mikroba, sehingga kinerjanya kurang optimal yang berdampak terhadap pertumbuhan tanaman menjadi kurang optimal.

\section{KESIMPULAN}


\begin{tabular}{ccrr}
\multicolumn{2}{c}{ Konsentrasi } & Bio & Organik \\
Herbafarm yang & & memberikan
\end{tabular} pertumbuhan dan hasil melon adalah 6.8 $\mathrm{ml}$ liter $^{-1}$ air, dengan berat buah optimal
1683.08 gram. Parameter ini diambil karena dianggap sebagai parameter representative dalam menggambarkan produksi melon di suatu daerah.

\section{UCAPAN TERIMA KASIH}

Terimakasih kepada seluruh teman-teman dan mahasiswa yang terlibat dalam penelitian ini, dan terimakasih

\section{DAFTAR PUSTAKA}

Anonim. 2012. Herbafarm bio organik. Penerbit PT. Nutriend International. Jakarta. Halaman 8.

Anianty A. 2008. Uji Efektivitas Pupuk Organik (Bio - Organic fertilizer) dalam Mensubtitusi Kebutuhan Pupuk pada Tanaman Caisin (Brassica chinensis). Institut Pertanian Bogor. Bogor.

Aritonang, S., \& Surtinah, S. (2018). Stimulasi Hasil Melon (Cucumis melo, L) Dengan Menggunakan Bioto Grow Gold (BGG). Jurnal Ilmiah Pertanian, 15(1), 35-41.

Asrul N, Rover dan Mashadi. 2012. Uji Beberapa Varietas dan Pemberian Pupuk Bio Organik Herbafarm Terhadap Pertumbuhan Dan Produksi Jagung Manis (Zea Mays Saccharata. Sturt). Jurnal Green Swarnadwipa, 3: 85-92

Elisabeth D. 2013. Pengaruh Pemberian Berbagai Komposisi Bahan Organik Pada Pertumbuhan dan Hasil Tanaman Bawang (Allium ascalonicum L). Universitas Brawijaya. Malang.

Isminarni., Wedhastri, dan Purwanto. 2007. Penambatan nitrogen dan Penghasilan Indol Asam Asetat oleh Isolat - Isolat Azotobacter pada $\mathrm{pH}$ Rendah dan Aluminium kepada Dekan yang sudah memfasilitasi pelaksanaan penelitian ini dalam bentuk dana penelitian.

Tinggi. Jurnal Ilmu Tanah dan Lingkungan, 7: 23-30.

Lestari, S., 2013. Pengujian Mikroorganisme Lokal (Mol) Buah-Buahan Busuk Terhadap Pertumbuhan dan Produksi Tanaman Selada (Lactuca sativa). Jurnal Ilmiah Pertanian, 10.(2):50-60

Matenggomena MF. 2013. Pemanfaatan sampah rumah tangga untuk budidaya tanaman sayuran organik di pekarangan rumah. Agroinovasi 17-23(3503):2-8.

Ode, S., dan Bahrun. 2012. Pengaruh Bahan Organik Dan Pupuk Kalium Terhadap Pertumbuhan Dan Produksi Tanaman Melon (Cucumis melo L). Jurnal Agroteknos, 2(2):69 -76.

Palimdungan, N., Labatar, R .O., dan Hamzah, H. 2006, Pengaruh Ekstrak Daun Lamtoro sebagai Pupuk Organik Cair Terhadap Pertumbuhan dan Produksi Tanaman Sawi. Jurnal Agristem, 2(2):96-121.

Setiadi dan Parimin. 2006. Bertanam Melon, Penebar Swadaya, Jakarta Simanungkalit, R. D. M., Didi,A. S., Rasti, S., Diah, S., Wiwik, H., 2006. Pupuk Organik dan Pupuk Hayati Organic Fertilizer. Balai Besar Penelitian dan 
Pengembangan sumberdaya Lahan Pertanian, Jawa Barat.

Syofia., Alridiwirsah dan Saleh, 2015. Respon Beberapa Varietas Dan Pemberian Pupuk Bio Organik Terhadap Pertumbuhan Dan Produksi Semangka (Citrullus vulgaris Schard). Jurnal Agrium, 19(3), 2442-7306.

Sudjianto dan Krestiani. (2009). Studi Pemulsaan dan Dosis NPK pada Hasil Buah Melon (Cucumis melo L). J. Sains Dan Teknologi, 2(2):1-7.

Sugiyono. 2007. Metode Penelitian Kuantitatif Kualitatif dan R\&D. Bandung: Alfabeta.

Supriyadi, M. 2009. Pengaruh Pupuk Kandang dan NPK Terhadap Populasi Bakteri Azotobacter dan Budidaya Cabai (Capsicum annum). Jurnal Bioscuence, 1:59-64

Surtinah, S. (2007). Menguji 5 Macam Pupuk Daun Dengan Mengukur Kadar Gula Total Biji Jagung Manis (Zea mays saccharata). Jurnal Ilmiah Pertanian, 3(2), 1-6.

Surtinah, S. (2008). Waktu Panen Yang Tepat Menentukan Kandungan Gula Biji Jagung Manis (Zea mays saccharata). Jurnal Ilmiah Pertanian, 4(2), 1-7.
Surtinah, S. (2017). Potensi Hasil Jagung Manis (Zea mays saccharata, Sturt) Dengan Pemberian Paket Teknologi Pupuk Dan Zat Pengatur Tumbuh. Jurnal BiBieT, 2(1), 37-44.

Surtinah, S. (2017). Evaluasi Deskriptif Umur Panen Melon (Cucumis melo, L) Di Pekanbaru. Jurnal Ilmiah Pertanian, 14(1), 65-71.

Surtinah, S., 2018 a. Agronomic Performance Of Sweet Corn (Zea mays saccharata, Sturt) In Rumbaidistrict

Pekanbaru. AGROLAND: The Agricultural Sciences Journal, 5(1), 53-58.

Surtinah, S. (2018 b). Korelasi Fenotype Dan Hasil Jagung Manis (Zea mays saccharata, Sturt) Di Kecamatan Rumbai Pekanbaru. Jurnal Ilmiah Pertanian, 15(1), 7-12.

Wahida dan Suryaningsih, 2016. Analisis Kandungan Unsur Hara Pupuk Organik Cair Dari limbah Rumah Tangga Di Kabupaten Marauke. Jurnal Agricola, Vol 6 (1), Hal:23-30.

Whitelaw, 2000. Growth Promotion Of Plants Inoculated With Phosphate Solubilizing Fungi . adv. Agron. 69:99151. 